\title{
Keratitis, Ichthyosis and Deafness (KID) Syndrome - a Case Report
}

\author{
${ }^{1}$ Special Hospital for Rehabilitation - Prolom Spa, AD Planinka Kuršumlija, Serbia \\ ${ }^{2}$ Faculty of Medicine, University of Niš, Serbia \\ *Correspondence: Mirjana PARAVINA, E-mail: mirjanaparavina@gmail.com
}

Milica STEPANOVIĆ ${ }^{1}$, Mirjana PARAVINA²*, Goran JANKOVIĆ1, Danica JANJIĆ SPASIĆ1

UDC 616.5-056.7-08:615.838

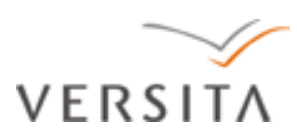

\begin{abstract}
Keratitis, ichthyosis and deafness (KID) syndrome is a rare congenital ectodermal dysplasia characterized by ichthyosiform hyperkeratosis of the skin, neurosensory hearing loss and vascularizing keratitis. It is inherited as an autosomal dominant trait, now known to be due to mutations in the connexin gene.

This paper presents a case of a 20 -year-old male patient with erythrokeratodermia and mild scaling since birth. He presented mild hearing impairment at the age of two and often suffered from eye inflammations. On admission, his clinical picture was typical of KID syndrome with erythrokeratodermia, neurosensory deafness, vascularizing keratitis, alopecia, palmoplantar keratosis, and nail dystrophy. The patient also had a history of recurrent infections, especially bacterial and candidal infections of the skin, auditory canals and eyes. Despite extensive skin, ocular, ear and hair manifestations, his physical and psychomotor growth and development were normal.

Adjuvant balneotherapy in Prolom Spa, along with emollient creams, significantly reduced cutaneous manifestations in our patient.
\end{abstract}

\section{Key words}

Keratitis; Ichtyosis; Deafness; Syndrome; Balneology; Baths; Treatment Outcome; Connexins

$\mathrm{K}^{\mathrm{c}}$ eratitis, ichthyosis and deafness (KID) syndrome is a rare congenital disorder which is included in the broad category of ectodermal dysplasias. The acronym was made in order to highlight the main features of the syndrome, skin lesions, neurosensory hearing loss and vascularizing keratitis $(1,2)$. Burns first described a disorder with these symptoms in 1915 (3), and Skinner et al, proposed KID as the term for this syndrome in 1981 (4). However, taking into consideration that keratitis is not present in all cases, and that the syndrome actually presents features of a hystrix-like ichthyosis combined with erythrokeratoderma, a new hystrix-like ichthyosis with deafness (HID) and KED (keratodermic ectodermal dysplasia) syndrome were proposed (5), but not accepted $(1,6)$. HID syndrome is now regarded as an allelic variant of KID (6).

\section{Case report}

A 20-year-old male patient was referred to Prolom Spa accompanied by his father.

Thepatient'shistory revealed erythrokeratodermia and mild scaling since birth. With time, erythematous hyperkeratotic plaques developed on elbows, knees, dorsal sides of hands and feet, with marked thickening (leather-like consistency) of palms and soles. Lesions spread to the face and the concha of the ears. Since the age of two, the patient frequently developed whole body erythema. At the same time, his parents observed hearing impairment as well. He often suffered from eye inflammations. The patient was treated by a dermatologist, ophtalmologist, otorinolaryngologist and visited a psychiatrist on a regular basis. His personal history revealed presence of documented 
bilateral keratopathy with corneal neovascularization, neurosensory hypoacusis and inguinal hernia for which he underwent surgery in childhood, as well as recurrent infections, especially bacterial and candidal infections of the skin, auditory canals and eyes. No other diseases were diagnosed. Family history showed no consanguinity, or similar disorders. The patient complained of itching, and had speech, hearing and vision problems. He suffered from insomnia in the past several months.

On admission, the patinet's whole body skin was diffusely thickened showing follicular keratosis. Prominent erythema affected the face and furrowing erythematous plaques were present around the mouth. Bilateral keratoconjunctivitis and corneal vascularization were also present (Figure 1). The patient presented with scalp hypotrichosis and scarring alopecia, with thick crusty squamous plaqes with rhagades showing sanguinolent exudation (Figure 2). The scalp hair was sparse, fine, brittle, pale in colour and slow growing. The eyebrows and eyelashes were thin or absent. Body, pubic and axillary hair was also affected.

Rough hyperkeratotic plaqes were found on the elbows, knees, dorsal aspects of the hands, and feet (Figures 3, 4, 5, 6). Diffuse palmoplantar hyperkeratosis was reticular in pattern and yellowish in color. All nail plates were short, thick, slow growing and yellowish.

Routine blood tests and urine analysis were within the range of reference values. The patient was examined by a psychiatrist and neurologist. The scores on the psychomotor development scale were within the normal range.

The therapy included direct topical application of peloid combined with bland emollient creams, mineral water baths and drinking of mineral water.

After 15 days of balneotherapy in Prolom Spa, the patient's skin has improved substantially (Figures 7-12). The erythema was less intense, hyperkeratosis has substantially reduced, keratodermic plaques on the scalp and rhagades have disappeared, and exudation has ceased. The itching was considerably reduced, and sleep restored.

\section{Discussion}

KID syndrome is a complex disorder of the ectodermal cell layer. In the developing embryo, this layer gives rise to a variety of tissues, thus, in addition to the skin, other ectodermal tissues are also affected, including corneal and inner ear epithelium (6). KID syndrome is a rare disorder. Most often it occurs sporadically in both sexes (7). According to literature data, during the period from its first description by Burns up to 2006 and 2012, over 90 and 100 cases of KID syndrome were reported, respectively $(8,9)$.

The main diagnostic criteria for KID syndrome include erythrokeratodermia, neurosensory deafness, vascularizing keratitis, palmoplantar keratosis and alopecia. The two latter are reminiscent of Clouston syndrome. According to the literature review of Caceres-Rios and associates (5), neurosensory deafness occurs in $90 \%$ cases, erythrokeratodermia in $89 \%$, vascularizing keratitis in $79 \%$, alopecia in $79 \%$, and reticular hyperkeratosis of palms and soles in $41 \%$. KID syndrome may also be associated with follicular keratosis, hypohidrosis, mental retardation, cryptorchidism, breast hypoplasia, short stature, oral ulcerations and dental anomalies, which emphasize the complexity and diversity of phenotypes caused by dominant-acting connexin mutations and the overlap in genotype/phenotype correlation in the connexin disorders (10).

Acneiform eruptions and cysts on the upper trunk are common, while chronic abscesses and discharging sinuses may present late complications in some patients such as in the case report on KID syndrome with follicular occlusion triad consisting of hidradenitis suppurativa, acne conglobata, and dissecting folliculitis of the scalp (perifolliculitis capitis abscedens et suffodiens) (11). Zhang and Li described a case of KID syndrome with the DandyWalker syndrome malformations of the posterior fossa eg., bilateral cerebral atrophy, left more prominent than right, and dysplasia of cerebellar vermis (12). One patient presented with tumors originating from hair follicle stem cells: specifically trichilemmal cysts in early lesions, proliferating trichilemmal tumors in moderate duration lesions, and malignant proliferating tumors in advanced lesions (13). Patients with KID syndrome present with a higher predisposition to develop cutaneous neoplasms (squamous cell carcinoma of the skin and tongue have been described in more than $10 \%$ of patients, and may occur during childhood) $(5,7,10$, 


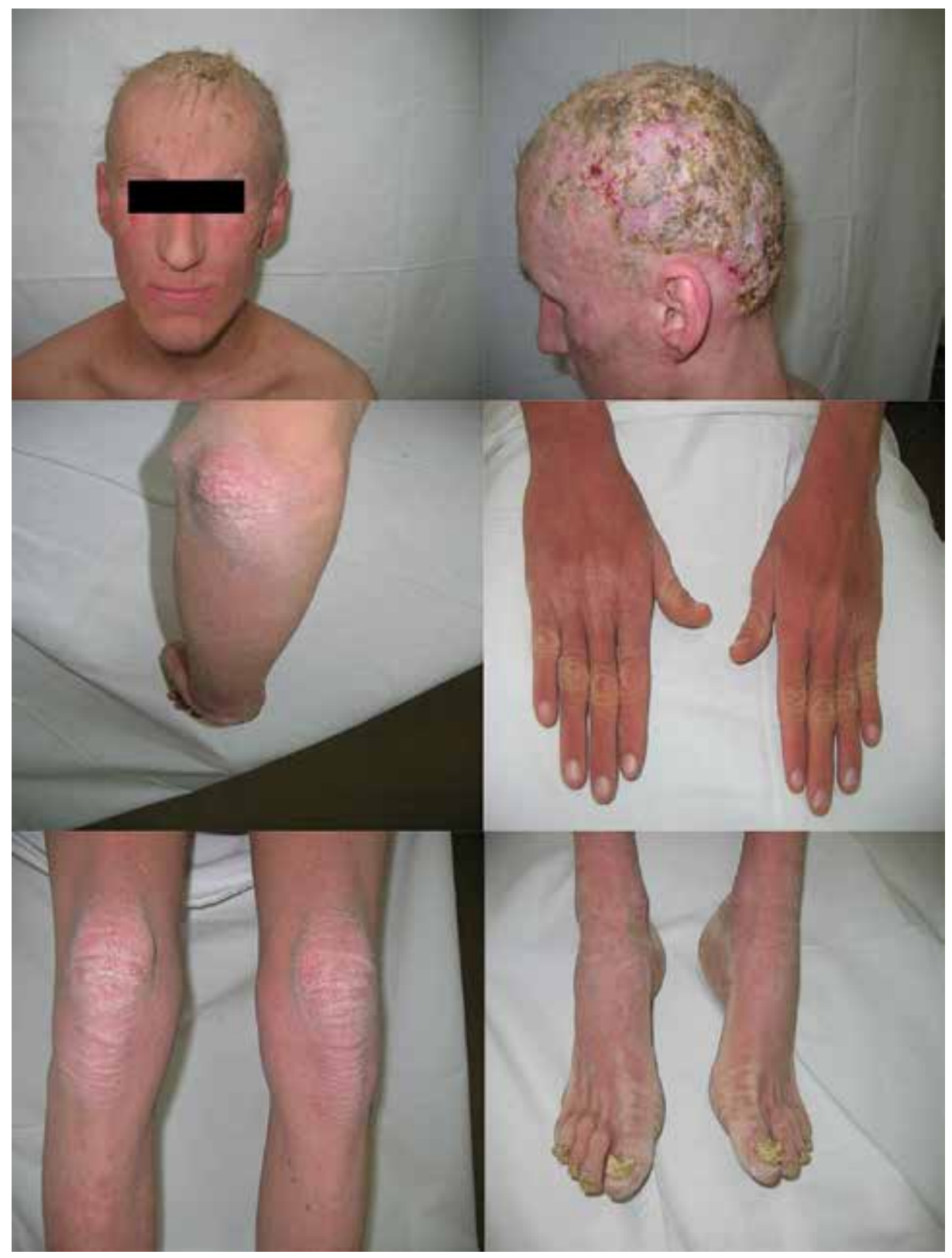

Figure 1. The patient before balneotherapy

14, 15), as well as infections (bacterial, fungal, and viral) $(10,16)$.

Histopathological and electron-microscopic findings of the skin are non-specific (17). Orthohyperkeratosis was reported, and hyperkeratotic plugs occluding the follicular and sudoriferous gland openings were described (7). The diagnosis is established by genetic tests or, after infancy, based on physical features (supported by audiological and ophthalmological evidence of neurosensory deafness and vascularizing keratitis in early childhood), just like in the majoity of other syndromes of ectodermal dysplasia (18).

A great number of sporadic cases were reported due to high rates of new mutations (8). Most reported cases of KID syndrome have been sporadic, but inheritance was evident in several families $(2,19$, 20). Although autosomal recessive inheritance was proposed (21), more recent literature shows evidence of spontaneous mutation inherited as an autosomal 
dominant trait (22). Mutation in gap junction proteins, namely connexins, has been considered a primary cause of the disorder and occurs in the GJB2 gene inconding connexin 26 (Cx26) (23). Cx26 is a gap junction protein which participates in the intra-cellular communication and controls cellular differentiation of ectoderm-derived epithelial layers of the cochlea, cornea, palmoplantar epidermis, sweat glands and ductal epithelium (8). Cx26 is also strongly expressed in the hair follicles (24). The commonest GJB2 mutation found in KID syndrome is the p.Asp50Asn mutation, which occurs in $80 \%$ of patients and accounts for most of the familial cases $(2,20)$. Patients with p.Ser17Phe mutation may present with serious forms of the disorder, with a higher risk for tongue cancer (2).

To emphasize the overlap in genotypephenotype correlation in the connexin disorders,

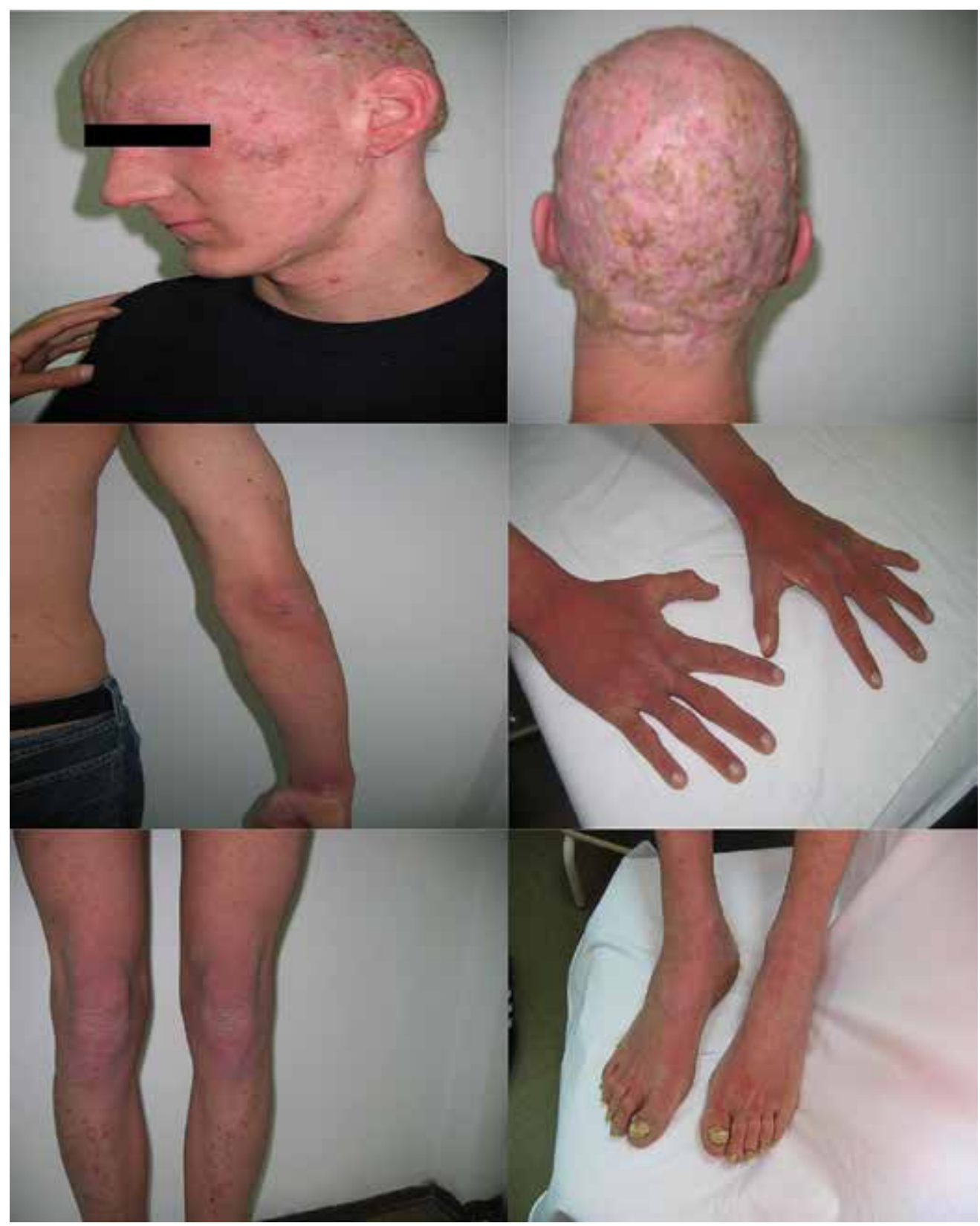

Figure 2. The patient after balneotherapy 
patients carrying identical mutations in $\mathrm{Cx} 30$ (V37E) have been shown to have classical Clouston syndrome (autosomal dominant hidrotic ectodermal dysplasia) and a KID syndrome-like phenotype (24). Jan and associates identified the mutation of GJB6 gene inconding Cx30 in a patient with KID syndrome and congenital atrichia (25). These support the genetic heterogeneity of the KID syndrome since mutation in $\mathrm{Cx} 26$ and $\mathrm{Cx} 30$ can cause overlapped phenotypes (25). Fozza and associates described a patient with KID syndrome and peripheral T-cell lymphoma, with a dilemma whether this was random association (26). Natsuga et al. examined the possibility of modifying effects (modifier genes are defined as genes that affect the phenotypic expression of another gene) of mutation in the keratin 17 gene on KID syndrome (27). However, due to the limited scope of this study (single case report) authors could not determine the clinical significance of the obtained findings (27).

Treatment of patients with KID syndrome requires a multidisciplinary approach. It is necessary to ensure cooperation among a dermatologist, ophthalmologist, otorhinolaryngologist, psychiatrist, speech therapist and other specialists if required. Skin changes should be treated with keratolytics and emollients administered topically, and antibiotics and antimycotics in case of secondary infections. Systemic administration of retinoids failed to yield satisfactory results (28). However, Zhang and associates reported good results when treating children with ichthyosis, though the exact risk/benefit ratio has not been fully established (29).

As far as the literature data available to us are concerned, there are no reports in the world literature on using balneotherapy in KID syndrome. Taking into consideration our treatment results, we believe that it would be useful to point out some features of the mineral water, peloids and mechanisms of action of balneotherapy in Prolom Spa.

In recent decades, balneotherapy has been rediscovered and there is an increased interest in studying effects of natural resources on human health. The main therapeutical factor of balneotherapy is the mineral water - natural solution formed under the effect of specific geological ingredients and "chemicalphysical dynamics", without microorganisms and with a great therapeutical potential. Fundamental and clinical investigations carried out in spas worldwide, showed therapeutical potentials for a great number of skin diseases, with a minimum risk of adverse effects $(30-39)$. Bathing in mineral water is safe, efficient and has beneficial effects on health and recovery. The therapeutical effect originates from local interactions between mineral water, peloids and skin surface.

Prolom water belongs to the category of sodium-hydrocarbonate, alkaline, oligomineral and hypothermal waters (40), and in terms of hydromorphology, it belongs to mineral waters of the "Serbian Crystal Core", coming from the depth of about $200 \mathrm{~m} \mathrm{(41).} \mathrm{The} \mathrm{water} \mathrm{temperature} \mathrm{is} 26-$ $31.5^{\circ} \mathrm{C}$, and $\mathrm{pH}$ ranges from 8.7 to 9.2 . It contains the following cations: $\mathrm{Na}, \mathrm{K}, \mathrm{Ca}, \mathrm{Mg}, \mathrm{Sr}, \mathrm{Fe}, \mathrm{Al}, \mathrm{Li}$, a weak electrolyte of metasilicic acid and free hydrogen sulphide gas.

Mineral water has mechanical, thermal and chemical effects (42). Mechanical effect is realized through hydrostatic pressure and thrust through mechanoreceptors and modified thermal and chemical effect, manifesting in increased skin permeability, increased penetration of minerals, keratolysis, increased muscle tonus and reduced pain intensity. Thermal effects include increased enzyme activity, accelerated catalytical biochemical processes, increased local metabolic processes, redistribution of blood, and sedation of the vegetative nervous system. Chemical matters from mineral waters and peloids may have indirect or direct effects on different organs and systems and modify the effects of thermal and mechanical factors (42). Chemical components of mineral waters and peloids cause morphological changes in the skin and its structures. The effects of balneotherapy on the skin include: skin softening, increased permeability, regulation of the skin surface layers (anti-proliferative effect), reduction of inflammation and irritation, increased resistance to microorganisms, anti-allergic effect, fast epithelialization, and improved microcirculation.

All these effects were manifested in our patient.

\section{Conclusion}

This paper presents a case of a patient suffering from a typical KID syndrome: erythrokeratodermia, 
neurosensory deafness, vascularizing keratitis, alopecia, palmoplantar hyperkeratosis, onychodystrophy and recurrent chronic skin infections.

Adjuvant balneotherapy, along with emollient creams, significantly reduced cutaneous manifestations in our patient.

\section{Abbrevations}

$$
\begin{aligned}
& \text { KID - Keratitis, ichthyosis and deafness } \\
& \text { HID - Hystrix-like ichthyosis with deafness } \\
& \text { KED - Keratodermic ectodermal dysplasia) }
\end{aligned}
$$

\section{References}

1. Lazic T, Horii KA, Richard G, Vasserman DI, Antaya RJ. A report of GJB2 (N14K) Connexin 26 mutation in two patients: a new subtype of KID syndrome? Pediatr Dermatol 2008;25(5):535-40.

2. Mazereeuw-Hautier J, Bitoun E, Chevrant-Breton J, Man SY, Bodemer C, Prins C, et al. Keratitis-ichthyosis-deafness syndrome: disease expression and spectrum of connexin 26 (GJB2) mutations in 14 patients. $\mathrm{Br} \mathrm{J}$ Dermatol 2007;156:1015-9.

3. Burns FS. A case of generalized keratoderma with unusual involvement of the eyes and nasal and buccal mucous membranes. J Cutan Dis 1915;33:255-60.

4. Skinner BA, Greist MC, Norins AL. The keratitis, ichthyosis, and deafness (KID) syndrome. Arch Dermatol 1981;117:2859 .

5. Caceres-Rios H, Tamayo-Sanchez L, Duran-Mckinster C, de la Luz Orozco M, Ruiz-Maldonado R. Keratitis, ichthyosis, and deafness (KID syndrome): review of the literature and proposal of a new terminology. Pediatr Dermatol 1996;13(2):105-13.

6. Judge MR, McLean WH, Munro CS. Disorders in keratinization. In: Burns T, Breathnach S, Cox N, Griffiths C, editors. Rook's textbook of dermatology. $6^{\text {th }}$ ed. Oxford: Blackwell Publishing Ltd; 2010. p. 19.1-122.

7. Alli N, Gungor E. Keratitis, ichthyosis and deafness (KID) syndrome. Int J Dermatol 1997;36:37-40.

8. Nyquist GG, Mumm C, Grau R, Crowson AN, Shurman DL, Benedetto P, et al. Malignant proliferating pillar tumours arising in KID syndrome. Am J Med Genet A 2007;143:73441.

9. Donnelly S, English G, de Zwart-Strom EA, Lang S, van Steensel MA, Martin PE. Differential susceptibility of Cx26 mutations associated with epidermal dysplasias to peptidoglycan derived from Staphylococcus aureus and Staphylococcus epidermidis. Exp Dermatol 2012;21:592-8.

10. Irvine AD, Mellerio JE. Genetics and genodermatoses. In: Burns T, Breathnach S, Cox N, Griffiths C, editors. Rook's textbook of dermatology. $6^{\text {th }}$ ed. Oxford: Blackwell Publishing Ltd; 2010. p. 15.1-97.

11. Montgomery JR, White TW, Martin BL, Turner ML, Holland SM. A novel connexin 26 gene mutation associated with features of the keratitis-ichthyosis-deafness syndrome and the follicular occlusion triad. J Am Acad Dermatol 2004;51:37782.

12. Zhang XB, Li CX. A case of keratitis ichthyosis deafness (KID) syndrome associated with Dandy-Walker. J Eur Acad Dermatol Venerol 2007;21:706-7.

13. Kim KH, Kim JS, Piao YJ, Kim YC, Shur KB, Lee JH, et al. Keratitis, ichthyosis and deafness syndrome with development of multiple hair follicle tumours. Br J Dermatol 2002;147:13943.

14. Kaku Y, Tanizaki H, Tanioka M, Sakabe J, MiyagawaHayashino A, Tokura Y, et al. Sebaceous carcinoma arising at a chronic candidiasis skin lesion of a patient with keratitis-ichthyosis-deafness (KID) syndrome. Br J Dermatol 2012;166:222-4.

15. Bergman R, Mercer A, Indelman M, Spricher E, Haim $\mathrm{N}$, Zoller L, et al. KID syndrome: histopathological, immunohistochemical and molecular analysis of precancerous skin lesions. Br J Dermatol 2012;166:455-7.

16. Gonzalez ME, Tlougan BE, Price HN, Patel R, Kamino H, Schaffer JV. Keratitis-ichthyosis-deafness (KID) syndrome. Dermatol Online J 2009;15(8):11.

17. Jovanović D, Paravina M, Stanojević M, Tiodorović J, Binić I, Milenković R, et al. Keratitis, ichthyosis and deafness (KID) syndrome: case study. Acta Med Median 1998;5:67-72.

18. Popadić S, Vujanac A, Arsov B, Ivanovski P, Nikolić M. Hypohidrotic ectodermal dysplasia: a case report. Serb J Dermatol Venereol 2011;3(3):109-12.

19. van Geel M, van Steensel M, Kuster W, et al. Hid and kid syndromes are associated with the same connexin 26 mutation. Br J Dermatol 2002;146:938-42.

20. Kelly B, Lozano A, Altenberg G, et al. Connexin 26 mutation in keratitis-ichthyosis-deafness (KID) syndrome in mother and daughter with combined conductive and sensorineural hearing loss. Int J Dermatol 2008;47:443-7.

21. Pavlović M. Nasledne keratoze dlanova i tabana [Congenital palmar and plantar keratoses]. U: Karadaglić Đ, ur. Dermatovenerologija. Beograd: Vojnoizdavački zavod; 2000. str. 468-82. (in Serbian).

22. Richard G, Rouan P, Willoughby CE, Brown N, Chung $\mathrm{P}$, Ryynanen $\mathrm{M}$, et al. Missense mutations in GJB2 encoding Connexin-26 cause the ectodermal dysplasia keratitis ichthyosis-deafness syndrome. Am J Hum Genet 2002;70:1341-8.

23. Markova TG, Brazhkina NB, Bliznets EV, Poliakov AV, Tavartkiladze GA. Diagnostics of keratitis-ichthyosisdeafness syndrome (KID-syndrome). Vestn Otorinolaringol 2012;(3):58-61.

24. Arita AK, Akiyama M, Tsuji Y, McMillan JR, Eady RA, Shimizu H. Gap junction development in the human fetal hair follicle and bulge region. Br J Dermatol 2004;150:429-34.

25. Jan AY, Amin S, Ratajczak P, Richard G, Sybert VP. Genetic heterogeneity of KID syndrome: identification of a Cx30 gene (GJB6) mutation in a patient with KID syndrome and congenital atrichia. J Invest Dermatol 2004;122:1108-13.

26. Fozza C, Poddie F, Contini S, Galleu A, Cottoni F, Longinotti $\mathrm{M}$, et al. Keratitis-ichthyosis-deafness syndrome, atypical connexin GJB2 gene mutation, and peripheral T-Cell lymphoma: more than a random association? Case Rep 
Hematol 2011;2011:ID848461.

27. Natsuga K, Shinkuma S, Kanda M, Suzuki Y, Choza N, Narita $\mathrm{Y}$, et al. Possible modifier effects of keratin 17 gene mutation on keratitis-ichthyosis-deafness syndrome. $\mathrm{Br} \mathrm{J}$ Dermatol 2012;166:903-5.

28. Nazzaro V, Blanchet-Bardon C, Lorette G, Civatte J. Familial occurrence of KID (keratitis, ichthyosis, deafness) syndrome. Case reports of a mother and daughter. J Am Acad Dermatol 1990;23(2 Pt 2):385-8.

29. Zhang X, He Y, Zhou H, Luo Q, Li C. Severe ichthyosisrelated disorders in children: response to acitretin. J Dermatol Treat 2007;18:118-22.

30. Dostanić I. Mogućnost lečenja psorijaze u Banji Kulaši [Possibilities of psoriasis treatment in Kulaši Spa]. Psorijaza 1990;2(2):21-4. (in Serbian).

31. Dostanić I. Mogućnost lečenja kožnih oboljenja u Bujanovačkoj Banji [Possibilities of treating skin diseases in Bujanovačka Spa]. Psorijaza 1991;3(3):39-41. (in Serbian).

32. Tranggono RI. The influence of spa products treatment for skin-care. J Appl Cosmetol 2000; 18(4):177-83.

33. Paravina M, Stepanović M, Račić G. Balneotherapy effectively acts on symptoms of psoriasis vulgaris. CEEDVA Bull 2002;4:70-2.

34. Merial-Kieny C, Castex-Rizzi N, Selas B, Mery S, Guerrero D. Avene thermal spring water: an active component with specific properties. J Eur Acad Dermatol Venereol 2011;25(Suppl 1):25.

35. Taieb C, Sibaud V, Merial-Kieny C. Impact of avene hydrotherapy on the quality of life of atopic and psoriatic patients. J Eur Acad Dermatol Venereol 2011;25(Suppl 1):24-9.

36. Merial-Kieny C, Mengual X, Guerrero D, Sibaud V. Clinical

\section{KID sindrom - prikaz slučaja}

\section{Sažetak}

Uvod. KID sindrom (eng. keratitis, ichthyosis, deafness) kongenitalni je nasledni epidermalni poremećaj koji se manifestuje kožnim lezijama, neurosenzornim gubitkom sluha i vaskularizujućim keratitisom. Uzrok oboljenja su mutacije u genu GJB2 koji kodira sintezu koneksina 26 (Cx26); koneksini (eng. connexin) jesu proteini koji učestvuju u unutarćelijskoj komunikaciji (eng. gap junction); Cx26 kontroliše ćelijsku diferencijaciju u tkivima poreklom iz ektoderma kao što su epitel unutrašnjeg uva i rožnjače, epidermis u palmoplantarnoj koži, folikulima dlake i znojnim žlezdama. Opisani su sporadični slučajevi obolelih do kojih dolazi zbog pojave novih spontanih mutacija, ali i slučajevi sa porodičnim javljanjem i autozomno dominantnim nasleđivanjem. efficacy of Avene hydrotherapy measured in a large cohort of more than 10,000 atopic or psoriatic patients. J Eur Acad Dermatol Venereol 2011;25(Suppl 1):30-4.

37. Bodemer C, Bourrat E, Mazereeuw-Hautier J, Boralevi F, Barbarot S, Bessis D, et al. Short- and medium-term efficacy of specific hydrotherapy in inherited ichthyosis. Br J Dermatol 2011; 165:1087-94.

38. Paravina M, Stepanović M, Račić G. Prirodni faktori Prolom Banje povoljno utiču na simptome Psoriasis vulgaris [Natural factors of Prolom Spa have possitive effects on syptoms of Psoriasis vulgaris]. U: VIII Beogradski dermatološki dani: zbornik radova [VIII Belgrade Dermatology Days: Proceedings]. Beograd; 2001. str. 98-100.

39. Stepanović M, Paravina M. Efekat balneoterapije na bolesnike sa ekcemom u Prolom Banji [Effects of balneotherapy in patients with eczema in Prolom Spa]. X Beogradski dermatološki dani: zbornik radova [X Belgrade Dermatology Days: Proceedings]. Beograd: SLD; 2003. str. 101-3.

40. Popović G. Kompletna fzičko-hemijska analiza mineralnih voda iz Prolom Banje [Complete physical and chemical analysis of mineral waters from Prolom Spa]. Beograd: Institut za rehabilitaciju-služba balneoklimatologije; 2003. str. 1-15. (in Serbian).

41. Đurđević S, Komatina M, Nikić Z, Međedović S, KomatinaPetrović S, Anđelski H, I dr. Pijaće mineralne vode: razvojna šansa Srbije [Drinking mineral waters: development opportunity for Serbia]. Beograd: Print Company; 2011. (in Serbian).

42. JovanovićT, urednik. Balneoklimatologija [Balneoclimatology]. Beograd: Medicinski fakultet; 1994.

Prikaz slučaja. Osoba muškog pola stara 20 godina upućena je na banjsko lečenje u Prolom banju u pratnji oca. Iz anamneze se saznaje da od rođenja ima promene na koži u vidu crvenila i ljuspanja. Vremenom se crvenilo smanjilo, ali su se javila zadebljanja na laktovima, kolenima, šakama i stopalima, na čelu i ušnim školjkama. Od druge godine života često se dešavalo da mu se zacrveni koža čitavog tela, njegovi roditelji su primetili da on slabije čuje, a često je imao i „zapaljenje očiju“. Lečili su ga: dermatolog, oftalmolog, otorinolaringolog i psihijatar. Od ranijih bolesti navodi da je operisan zbog ingvinalne kile. Iz porodične anamneze se saznaje da nije bilo obolelih srodnika ni konsangviniteta.

Dermatološki status na prijemu. Koža celog 
tela bila je difuzno zadebljala sa folikularnom keratozom dok su na licu dominirali eritem i izbrazdane eritematozne ploče oko usta; obostrano sklere su bile injicirane; na kosmatom delu glave bila je prisutna hipotrihoza sa ožiljnom alopecijom, naslagama debelih krustoskvama, ragadama i secerniranjem sukrvičavog sadržaja; obrve su bile znatno proređene, trepavice su nedostajale, kao i dlake na telu u aksilarnoj i pubičnoj regiji; na laktovima i kolenima dominirali su grubi hiperkeratotični plakovi; difuzna palmoplantarna hiperkeratoza imala je mrežast izgled sa žućkastim koloritom; nokatne ploče su bile zadebljale, žućkasto prebojene; na dorzumima šaka i stopala i prstima ruku i nogu bili su prisutni keratotični plakovi. Od subjektivnih tegoba pacijent je naveo osećaj svraba, postojao je poremećaj sna, govora, sluha i vida.

Laboratorijski nalazi. Rezultati rutinskih anliza uključujući i osnovne biohemijske parametre bili su u granicama referentnih vrednosti.

Konsultativni pregledi. Izveštaji konsultovanih specijalista (prema priloženoj pismenoj dokumentaciji), govorili su o prisustvu keratopatije $s$ neovaskularizacijom kornee, neurosenzornom smanjenju sluha i očuvanom psihomotornom razvoju.

Terapija. U toku 15 dana boravka u Prolom banji, primenjeni su peloid direktno na kožu, emolijentne kreme, podvodna masaža i pitke kure sa mineralnom vodom.

Efekti terapije. Nakon petnaestodnevnog lečenja, stanje na koži je značajno poboljšano: eritem i hiperkeratoza su značajno smanjeni, sa kože poglavine su uklonjene keratodermijske ploče, ragade su epitelizovale, eksudacija je sanirana; svrab je postao znatno manji; vratio se san.

Diskusija. KID sindrom predstavlja kompleksni poremećaj ektoderma, u kome su pored epidermisa zahvaćenai druga ektodermalna tkiva, epitel rožnjače i unutrašnjeg uva. Glavni dijagnostički kriterijumi su: eritrokeratodermija, neurosenzorna gluvoća, vaskularizujući keratitis, alopecija i palmoplantarna keratoza, dva poslednja prisutna su i u Cloustonovom sindromu (hidrotska ektodermalna displazija). Oboleli od KID sindroma takođe mogu ispoljiti folikularnu keratozu, hipohidrozu, mentalnu retardaciju, kriptorhizam, hipoplaziju dojki, nizak rast, oralne ulceracije i anomalije zuba, što govori o složenosti i mogućim preklapanjima između raličitih genotipova/fenotipova izazvanih mutacijama u koneksin genima. Najčešća GJB2 mutacija u KID sindromu je, p.Asp50Asn mutacija: ona je prisutna kod oko $80 \%$ obolelih, i odgovorna je za najveći broj porodičnog javljanja sindroma. Kod osoba koje imaju p.Ser17Phe mutaciju može se razviti teža manifestacija bolesti sa povišenim rizikom od dobijanja karcinoma jezika. O prisustvu preklapanja između različitih genotipova ifenotipova kod osoba kod kojih postoje poremećaji koneksina govori i prisustvo identične V37E mutacije u Cx30 (GJB2) genu kod osoba koje imaju znake klasičnog Cloustonovog sindroma i osoba sa KID fenotipom. Takođe, dokazana je mutacija na GJB6 genu koji kodira sintezu Cx30 kod osobe sa KID sindromom i kongenitalnom atrihijom. Genetska heterogenost KID sindroma ogleda se znači u preklapanju fenotipova koje izazivaju mutacije na dva različita gena koji kodiraju sintezu Cx26 (GJB2) i Cx30 (GJB6) koneksina.

Oboleli imaju povišen rizik za nastanak karcinoma skvamoznih ćelija kože i jezika i za razvoj infekcija (bakterijskih, gljivičnih, virusnih).

Za lečenje kožnih promena lokalno se primenjuju: keratolitici i emolijensi, u slučajevima sekundarne infekcije antibiotici i antimikotici; sistemska primena retinoida nije dala očekivane terapijske efekte.

U nama dostupnoj literaturi nismo našli podatke o primeni balneoterapije kod KID sindroma. S obzirom na naše rezultate lečenja smatramo da je korisno da obrazložimo osobine mineralne vode i peloida i mehanizme dejstva primenjene terapije $\mathrm{u}$ Prolom banji.

Pod uticajem hemijskih komponenti mineralnih voda i peloida dolazi do morfoloških promena na koži i njenim strukturama. Efekti balneoterapije na koži su: omekšavanje kože, povećanje propustljivosti, regulacija površnih slojeva kože (antiproliferativno dejstvo), redukcija inflamacije, redukcija iritacije, povećanje rezistencije na mikroorganizme, antialergijski efekat, brza epitelizacija, poboljšanje mikrocirkulacije. Svi navedeni efekti su doveli do značajnog poboljšanja kod našeg pacijenta. 
Zaključak. Prikazan je bolesnik sa tipičnom slikom KID sindroma: eritrokeratodermija, neurosenzorna gluvoća, vaskularizujući keratitis, alopecija, palmoplantarna hiperkeratoza, onihodistrofija i rekurentne hronične infekcije. Adjuvantna balneoterapija je u kombinaciji sa emolijentnom kremom ublažila kutane manifestacije ovog sindroma.

\section{Ključne reči}

Keratitis; Ihtioza; Gluvoća; Sindrom; Balneologija; Kupke; Ishod lečenja; Koneksini 